\title{
PERTANGGUNGJAWABAN HUKUM DOKTER PROGRAM INTERNSIP DALAM PELAYANAN KESEHATAN TERHADAP PASIEN
}

\author{
Ade Irwanto, ${ }^{1}$ Fakhruddin Razy ${ }^{2 *}$ \\ ${ }^{1,2}$ Fakultas Humaniora, Universitas Sari Mulia Banjarmasin, Indonesia \\ *razyf1463@gmail.com (corresponding).
}

\begin{abstract}
Suppose there is a problem related to the loss incurred to the patient when the doctor of the Internship program does not meet the established educational standards. In that case, health services will be exposed to a greater risk of civil liability if they ignore internal arrangements related to internal physicians. The risk of joint civil litigation will be very burdensome for interns and hospitals if hospital leaders issue wrong clinical assignments. Hospitals need to be aware that material and substance cannot be compared between hospitals and hospitals. Each hospital should ask their medical committee to arrange bylaws related to implementing the profession of interns in their respective hospitals. The approach used in this study is the method of the Legislative Approach (Statue Uproach), Conceptual Approach, and Sociological Approaches. By law anyone who causes or incurs a loss to another person is required to account for any such loss. Likewise, doctors, as health workers who have provided health services (medical measures) to patients, if the doctor incurs losses with these services, are obliged to provide accountability. The responsibility of doctors who commit malpractice can be punched in 3 (three) aspects: civil, criminal, and administrative matters.
\end{abstract}

Keywords: Responsibility; Internship Doctor; Medical Implementation

\section{PENDAhuluan}

Pendidikan profesi dokter diharuskan untuk menyelenggrakan program internsip dokter. Program internsip kedokteran dilaksanakan berdasarkan Peraturan Menteri Kesehatan No. 299/MENKES/PER/II/2010 tentang Penyelenggaraan Program Internsip dan Penempatan Dokter Pasca Internsip, serta Peraturan Konsil Kedokteran Indonesia No. 1/KKI/PER/I/2010 tentang Registrasi Dokter Program Internsip (IDAI, 2011).

Program internsip adalah proses pemanfaatan mutu profesi dokter untuk menerapkan kompetensi yang diperoleh selama pendidikan, secara terintegrasi, komprehensif, mandiri serta menggunakan pendekatan kedokteran keluarga dalam rangka pemahiran dan penyelarasan antara hasil pendidikan dengan praktik di lapangan (Fourianalistyawati, 2012). Undang-Undang Nomor 
36 Tahun 2009 Tentang Tenaga Kesehatan, Pasal 1 Angka 6 mengatur bahwa "Tenaga kesehatan adalah setiap orang yang mengabdikan diri dalam bidang kesehatan serta memiliki pengetahuan dan/atau keterampilan melalui pendidikan di bidang kesehatan yang untuk jenis tertentu memerlukan kewenangan untuk melakukan upaya kesehatan."

Seorang tidak dibenarkan melakukan tidakan pelayanan kesehatan apabila tidak memiliki keterampilan, pengetahuan termasuk pengalaman yang sesuai ketentuan terkait mengenai bagaimana langkah dan upaya dalam melaksanakan pelayanan kesehatan terhadap seorang pasien (Astuti, 2003). Hal ini karena kesehatan sangat berkaitan dengan kelangsungan hidup seseorang yang jika menyalahi ketentuan pelayanan dapat berakibat buruk pada pasiennya. Hal ini diatur dalam Undang-Undang Nomor 29 Tahun 2004 tentang Praktik Kedokteran Pasal 73 Ayat (2) bahwa: "Setiap orang dilarang menggunakan alat, metode atau cara lain dalam memberikan pelayanan kepada masyarakat yang menimbulkan kesan seolah-olah yang bersangkutan adalah dokter atau dokter gigi yang telah memiliki surat tanda registrasi dan/atau surat izin praktik."

Dalam hal ini adanya hubungan hukum antara dokter dengan pasien terbentuk karena adanya perjanjian (Sukohar, Sibero, \& Ratna, 2015). Perjanjian terbentuk karena adanya hubungan hukum antara dokter dengan pasien, dimana pasien memberikan kepercayaan terhadap dokter secara langsung, yang didasarkan pada hak dan kewajiban yang timbul dari masing-masing pihak yang diatur oleh hukum. Hak adalah kewenangan yang diberikan hukum kepada subjek hukum, sedangkan kewajiban adalah beban yang diberikan oleh hukum kepada subjek hukum. Hubungan hukum adalah hubungan antara subjek hukum ataupun subjek hukum dengan objek hukum yang diatur oleh hukum (Nasution, 2005).

Adapun hak-hak pasien dalam hal ini yaitu: hak atas informasi, hak untuk memberikan persetujuan, hak atas rahasia dokter, hak memilih dokter dan hak memilih sarana kesehatanan dan sebgainya. Sedangkan kewajiban seorang dokter dalam hal ini yaitu: setiap dokter wajib melakukan pertolongan darurat sebagai suatu tugas prikemanusian, dokter wajib merawat pasiennya dengan cara keilmuan yang dimiliki, setiap dokter wajib bersikap tulus ikhlas dan mempergunakan segala ilmu dan keterampilannya untuk kepentingan pasien, dan setiap dokter wajib merahasiakan segala sesuatu yang diketahuinya tentang seorang pasien, bahkan juga setelah pasien itu meninggal dunia (Zaeni, 2017).

Apabila terjadi suatu permasalahan yang terkait mengenai kerugian yang akan ditimbulkan terhadap pasien ketika dokter program Internsip ini tidak memenuhi standar pendidikan yang ditetapkan maka, pelayanan kesehatan akan terpapar pada risiko tanggunggugat perdata yang lebih besar bila tidak mencermati pengaturan internal terkait dokter internsip. Resiko tanggung renteng gugatan perdata akan amat membebani dokter internsip dan rumah sakit apabila dikeluarkan penugasan klinis yang keliru oleh pimpinan rumah sakit (Sooewono, 2007). Rumah sakit perlu mencermati bahwa materi dan substansi tidak mungkin disamakan antara satu rumah sakit dengan rumah sakit lainnya. Setiap rumah sakit sudah seyogyanya meminta komite medisnya untuk menyusun bylaws terkait pelaksanaan keprofesian dokter internsip dirumah sakit masing-masing. Adanya perangkat-perangkat ini akan membantu pelaksanaan pelayanan kesehatan di rumah sakit dan menghindarkan tenaga kesehatan serta rumah sakit dari masalah etik, disiplin,dan hukum ke depan (Bertens, 2011). 
Selanjutnya, hal ini dokter tidak hanya bertanggungjawab terkait kesalahan yang dilakukannya sendiri tapi juga menyangkut kesalahan para medik yang membantu kegiatan pelayanan kesehatan yang dilaksanakannya seperti perawat, bidan, dokter yang baru lulus pendidikan kedokteran, dan sebagainya. Hal ini sebagai akibat dari pertanggungjawaban profesi seorang dokter yang bertanggungjawab terhadap apa yang dilaksanakan oleh orang-orang yang dibawah kuasanya dimana mereka harus melaksanakan kegiatan pelayanannya sesuai dengan apa yang di perintahkan oleh dokter. Hal ini berdasarkan Pasal 1367 KUHPerdata (H.S., 2013).

Penelitian terdahulu yang sudah dilakukan dalam topik yang sama, tercatat menunjukkan hasil dan temuan yang belum memuaskan. Erwin G. Kristanto membahas tentang tanggungjawab dokter internsip dari segi medis saja (Erwin G. Kristanto, 2012). Sedangkan Rozi Kodarusman Warganegara membahas perlindungan hukum terhadap dokter internsip dalam pelayanan kesehatan di wahana internsip meliputi rumah sakit dan puskesmas. Sehingga, penelitian tentang pertanggungjawaban hukum dokter internsip terhadap pasien merupakan penelitian yang unik dan memiliki novelty yang sangat kuat.

Oleh karena itu, banyaknya kasus malpraktik yang terjadi dalam proses penanganan medis menjadikan masyarakat lebih waspada dan kritis dalam menjalani proses pelayanan medik, maka dari itu peneliti tertarik melakukan kajian mengenai Bagaimanakah pertanggungjawaban dokter program Internsip terhadap kesalahan dalam tindakan pelaksanaan medis.

\section{METODE PENELITIAN}

Dalam penelitian ini peneliti menggunakan metode Penelitian Normatif (Irwansyah, 2020). Metode tersebut adalah suatu pendekatan yang dilakukan untuk mengkaji peraturan perundangundangan, norma-norma, kaidah-kaidah, konsep-konsep hukum, dan pendapat para ahli hukum yang terdapat dalam berbagai kepustakaan atau literatur yang terkait langsung dengan objek penelitian ini (Peter Mahmud Marzuki, 2014)(Zubaidi, Pratamab, \& Al-Fatih, 2020).

Dalam penelitian ini, digunakan 3 (tiga) metode penelitian untuk mengkaji permasalahan sebagaimana dikemukakan dalam penelitian ini. Metode yang dimaksud adalah:

1. Pendekatan Perundang-undangan (Statue Aproach).

Pendekatan Perundang-undangan (Sulaiman, 2018), yaitu kegiatan meneliti peraturan Perundang-undangan, asas-asas, maupun norma-norma hukum yang hidup dalam masyarakat, terutama yang berkaitan dengan masalah yang dikaji yaitu tentang tinjauan yuridis tanggung jawab hukum keperdataan dokter program Internsip.

2. Pendekatan Konseptual (Conceptual Aproach).

Pendekatan Konseptual, yaitu kegiatan mengkaji pandangan- pandangan para ahli berkenaan dengan masalah masalah yang dibahas (Likadja, 2015).

3. Pendekatan Sosiologis (Sociological Approach).

Pendekatan sosiologis yaitu suatu pendekatan yang dapat menjelaskan hukum sebagai suatu fenomena sosial, menjelaskan hubungan antara hukum dengan perilaku sosial, hubungan hukum dengan perubahan sosial, hubungan hukum antara hukuum dengan fakta sosial (Indriati, Wahyuningsih, Sanyoto, \& Suyadi, 2018). 


\section{HASIL DAN PEMBAHASAN}

Internsip adalah proses pemanfaatan mutu profesi dokter dan dokter gigi untuk menerapkan kompetensi yang diperoleh selama pendidikan, secara terintegrasi, komprehensif, mandiri serta menggunakan pendekatan kedokteran keluarga dalam rangka pemahiran dan penyelarasan antara hasil pendidikan dengan praktik dilapangan. Program Internsip merupakan tahap pelatihan keprofesian pra-registrasi berbasis kompetensi pelayanan primer guna memahirkan kompetensi yang telah dicapai setelah memperoleh kualifikasi sebagai dokter melalui pendidikan kedokteran dasar.

Peserta program Internsip adalah dokter baru lulus Program Pendidikan Dokter berbasis kompetensi yang akan menjalankan praktik kedokteran dan/atau mengikuti pendidikan dokter spesialis. Distribusi peserta Program Internsip Dokter Indonesia diatur oleh Komite Internsip Dokter Indonesia. Sebelum menjalankan program Internsip, peserta sudah lulus Uji Kompetensi Dokter Indonesia (UKDI), serta memiliki Surat Tanda Registrasi (STR) untuk Kewenangan Internsip dan Surat Izin Praktik (SIP) Internsip (Erwin G. Kristanto, 2012). Penyelenggaraan pelaksanaan Program Internsip oleh Komite Internsip Dokter Indonesia bekerjasama dengan pemangku kepentingan Penempatan Dokter baru pada wahana program Internsip dilakukan oleh KIDI bekerjasama dengan KIDI Provinsi dan Berkoordinasi dengan Dinas Kesehatan Provinsi Kabupaten/Kota.

Secara hukum siapa pun juga yang menimbulkan atau mendatangkan kerugian pada orang lain diharuskan untuk mempertanggungjawabkan segala kerugian tersebut. Demikian juga dengan dokter (Tutik, 2010), sebagai tenaga kesehatan yang telah memberikan pelayanan kesehatan (tindakan medis) kepada pasien, dalam hal dokter mendatangkan kerugian dengan pelayanannya tersebut, wajib untuk memberikan pertanggungjawaban. Tanggung jawab dokter yang melakukan malpraktik dapat ditinju dari 3 (tiga) segi (Muchtar, 2016), yaitu dari segi keperdataan, kepidanaan dan administrasi.

\section{Tanggung Jawab Keperdataan}

Dari segi keperdataan tanggungjawab seorang dokter jika melakukan kesalahan dalam menjalankan profesinya (malpraktik) terbatas pada tanggung jawab yang timbul sebagai akibat adanya kontrak/perjanjian yang terjadi antara kedua belah pihak (dokter dan pasien) (Sooewono, 2007). Dalam hal yang demikian maka dokter yang tidak menjalankan profesinya secara keperdataan dapat dituntut bahwa yang bersangkutan telah melakukan wanprestasi (Pasal 1239 KUHPerdata), melakukan perbuatan melanggar hukum (Pasal 1365 KUHPerdata), dan melakukan kelalaian yang mengakibatkan kerugian (Pasal 1366 KUHPerdata).

2. Tanggung Jawab Hukum Kepidanaan

Tanggung jawab kepidanaan dalam hubungan dokter dan pasien dapat muncul dalam tindakan tindakan medis yang dilakukan oleh dokter terhadap pasiennya. Dalam melakukan suatu tindakan seorang dokter seringkali berhadapan dengan masalah-masalah: 
a. Tindakan atas dasar indikasi medis hanya dapat dilakukan setelah adanya persetujuan pasien.

b. Tindakan atas dasar indikasi medis tanpa adanya persetujuan pasien. Seorang dokter yang melakukan tindakan medis tanpa persetujuan pasien, seorang pasien dapat dituntut telah melakukan kekerasan sesuai ketentuan pasal 89 KUHP "membuat seseorang pingsan atau tidak berdaya".

c. Tindakan tanpa dasar tindakan medis dengan persetujuan pasien. Contoh Operasi Plastik.

Secara umum dalam pelaksanaan profesi dokter program Internsip di rumah sakit. Rumah sakit sebagai pelaksana pelayanan kesehatan bertanggungjawab untuk menyediakan sarana yang mendukung pelaksanaan profesi dokter program Internsip. tujuan program Internsip dokter secara khusus yaitu: untuk mengintegrasikan pengetahuan, keterampilan dan sikap yang diperoleh selama pendidikan dan menerapkan dalam pelayanan primer; Mengembangkan keterampilan teknis, klinis, pribadi dan profesi yang menjadi dasar praktik kedokteran; Memikul tanggung-jawab pelayanan pasien sesuai kewenangan yang diberikan; Meningkatkan kemampuan dalam pembuatan keputusan profesional media dalam pelayanan pasien dengan memanfaatkan layanan diagnostik dan konsultasi.

Dalam hal ini dokter program Internsip ini tidak sendiri tapi didampingi oleh dokter Pendamping dimana seorang dokter pendamping ini bertugas untuk membimbing mendampingi dokter yang melakukan program Internsip ini selama dokter program Internsip ini masih menjalankan program Internsipnya dirumah sakit. Dokter pendamping yaitu dokter yang masih aktif praktek minimum 2 tahun, bersedia mengikuti pelatihan menjadi pendamping dan bersedia secara aktif melakukan tugas pendampingan. Dokter pendamping program Internsip bertanggungjawab memberi bimbingan dan arahan kepada dokter Internsip.

Sanksi pelanggaran terhadap dokter Internsip mengacu pada peraturan dan yurisprudensi hukum mengenai tenaga kesehatan. Selama proses hukum, program internsip peserta yang bersangkutan akan ditunda sampai diperoleh putusan berkekuatan hukum tetap. Sanksi pidana dan atau perdata dapat diikuti oleh sanksi administratif sesuai yang ditetapkan dalam peraturan menteri kesehatan dan peraturan konsil kedokteran Indonesia tentang dokter internsip.

Dokter program Internsip bertanggungjawab secara hukum apabila terjadi kesalahan yang di lakukannya. Hal itu akan dikoordinasikan ke bidang komite Internsip dan akan dibahas secara bersama antara pihak wahana Internsip dan dokter pendamping di rumah sakit. Dokter Internsip bekerja dibawah bimbingan atau arahan dari dokter pendamping. Dokter Internsip boleh melakukan tindakan yang bersifat mandiri tanpa persetujuan dokter pendamping. Apabila dokter pendamping tidak ada dilokasi dan apabila dalam hal mendesak, seperti kecelakaan lalu lintas, itu boleh diambil alih oleh dokter Internsip tanpa perlu meminta izin kepada dokter pendamping.

Adapun untuk menentukan bentuk pertanggungjawaban apa yang harus dilakukan apabila dokter Internsip melakukan kesalahan dalam pelaksanaan tindakan medis maka dapat dilihat dari 
segi kesalahannya seperti apa, dan bagaimana sampai terjadi kesalahan yang dimaksud. Jika kesalahan itu dilakukan oleh dokter Internsip tanpa adanya perintah atau pelimpahan wewenang untuk melakukan pelayanan kesehatan dari pendampingnya, maka tentunya yang bertanggungjawab adalah dokter Internsip sendiri. dalam hal ini kesalahan terjadi karena akibat adanya kelalian atau ketidaksengajaan dokter Internsip. Selain itu, untuk menentukan sanksi terlebih dahulu harus dipelajari bagaimana bentuk kesalahannya, apakah merupakan kesalahan yang berakibat fatal terhadap pasien atau tidak.

Dari keterangan diatas, menjelaskan bahwa terkait siapa yang bertanggungjawab tentu harus dipelajari bagaimana kesalahannya, Bentuk kesalahan yang harus di pahami dalam hal ini maksudnya adalah bahwa jika hanya terkait mengenai tata tertib dan kesalahan yang sifatnya ringan dan dapat diselesaikan tanpa harus melibatkan wahana atau rumah sakit, maka tentunya yang bertanggung jawab adalah dokter intreship itu sendiri. Jika kesalahan yang dimaksud merupakan kesalahan fatal yang berakibat pada kerugian pihak pasien yang memungkinkan pasien menuntut dokter Internsip in maka tentu diserahkan kepada pihak pendampingnya dan wahana Internsip untuk menanggapi dan jika memungkinkan dokter Internsip ini akan dikenakan sanksi.

Pertanggungjawaban muncul ketika kegiatan pelayanan yang dilakukan oleh dokter Internsip tidak sesuai dengan perjanjian pelayanan kesehatan yang dilakukan terhadap pasien, termasuk ketika adanya pelayanan kesehatan yang dilakukan dan bertentangan dengan Undang-Undang misalkan ketika dokter Internsip mengambil keputusan secara mandiri untuk melakukan praktik pelayanan kesehatan sementara dokter Internsip tersebut tidak memiliki kewenangan untuk melakukan itu, dokter Internsip mengabaikan instruksi atau arahan dari dokter pendamping untuk melakukan kegiatan pelayanan tertentu terhadap pasien yang keseluruhan itu berakibat pada kerugian yang dialami oleh pasien.

\section{Bentuk Pertanggung Jawaban dan Sanksi}

Bentuk pertanggungjawaban yang dibebankan kepada pihak yang bertanggungjawab dalam hal ini dokter pendamping atau wahana Internsip tentunya harus terlebih dahulu mempelajari bentuk kesalahannya, dan bagaimana proses terjadinya kesalahan. Jika kesalahan hanya bersifat pelanggaran etika yang dilakukan oleh dokter Internsip misalnya terlambat datang, maka hanya akan dibebankan tugas tambahan dan seterusnya.

Untuk kesalahan yang dilakukan oleh dokter internship misalkan kesalahan memberikan resep, kesalahan dalam pengambilan dan pemeriksaan darah, maka biasanya yang bersangkutan akan di perpanjang masa internsipnya pada bagian tersebut atau dinyatakan tidak lulus dan yang bersangkutan diharuskan untuk mengulangi kembali program Internsip pada bagian spesialisasi tersebut. Apabila kesalahan dokter Internsip tersebut merupakan kesalahan berat dan berakibat pada kerugian terhadap pasien dalam proses pengobatannya misalnya kesalahan pemberian resep yang mengakibatkan pasien lebih menderita terhadap penyakitnya, maka oleh yang bersangkutan dapat dikenakan sanksi skorsing untuk waktu yang telah di tentukan bahkan jika terlalu berat, maka yang 
bersangkutan dapat dikenakan sanksi hukum sesuai aturan yang berlaku hingga dikeluarkan sebagai peserta program Internsip.

Secara keseluruhan Dokter Internsip, Dokter Pendamping dan Wahana Internsip bertanggungjawab secara hukum terhadap kesalahan sesuai dengan bagaimana bentuk kesalahannya (Mubasyiroh, Despitasari, \& Hendarwan, 2018). Jika kesalahan tersebut mengharuskan pihak wahana Internsip bertanggung jawab secara kelembagaan, maka wahana Internsip dalam hal ini tentu mempertanggung jawabkannya secara kelembagaan termasuk menanggung ganti rugi yang di tanggung pasien terhadap kesalahan yang dilakukan oleh dokter Internsip tersebut. Dari keterangan diatas menjelaskan bahwa bentuk pertanggungjawaban yang dilakukan terkait kesalahan yang dilakukan oleh dokter Internsip dalam pelayanan kesehatan terhadap pasien harus melalui pemeriksaan dan pendalaman terhadap kesalahan tersebut. Untuk menentukan sanksi harus memeriksa bagaimana bentuk dan besaran kesalahan akan tetapi secara kelembagaan pihak wahana Internsip bertanggungjawab jika terdapat kesalahan yang dilakukan oleh dokter Internsip tersebut. Dalam pendalaman terhadap bagaimana kesalahan tersebut, wahana Internsip melakukan pemeriksaan bekerjasama dengan pihak rumah sakit untuk menentukan bagaimana bentuk dan kedudukan kesalahan yang dimaksud guna menarik kesimpulan dan menentukan sanksi yang sesuai dalam Peraturan Menteri Kesehatan Republik Indonesia No.2052/Menkes/Per/X/2011 Tentang Izin Praktik Dan Pelaksanaan Praktik Kedokteran, bahwa:

Pasal 31 Ayat (1) mengatur bahwa:

Dalam rangka pembinaan dan pengawasan, Kepala Dinas Kesehatan Kabupaten/Kota dapat mengambil tindakan administratif terhadap pelanggaran Peraturan Menteri ini. Ayat (2) mengatur bahwa:

Sanksi administratif sebagaimana dimaksud pada ayat (1) dapat berupa peringatan lisan, tertulis sampai dengan pencabutan SIP.

Ayat (3) mengatur bahwa:

Kepala Dinas Kesehatan Kabupaten/Kota dalam memberikan sanksi administratif sebagaimana dimaksud pada ayat (2) terlebih dahulu dapat mendengar pertimbangan organisasi profesi.

Dari berbagai aturan tersebut, tidak menjelaskan secara khusus hak dan wewenang dokter pendamping, hak dan wewenang dokter Internsip dalam melakukan pelayanan kesehatan terhadap pasien di rumah sakit, termasuk bentuk pemberian sanksi terhadap dokter pendamping dan dokter Internsip terkait kesalahan yang dilakukannya. Hal ini menurut peneliti dianggap perlu mengingat pelayanan kesehatan yang dilakukan oleh dokter Internsip terhadap pasien merupakan hal yang serius dimana pelayanan kesehatan tersebut berakibat langsung pada kondisi kesehatan pasien selama menjalani perawatan di rumah sakit (Irfan \& Hidayat, 2018).

Semua keputusan terkait kesalahan meskipun pemeriksaannya melibatkan semua pihak akan tetepi hanya pihak wahana Internsiplah yang menentukan bagaimana bentuk sanksi yang dijatuhkan jika terjadi kesalahan dan hal ini merupakan keputusan internal tanpa melibatkan pihak pasien dalam penentuan sanksi tersebut. Oleh karena itu menurut peneliti, perlu adanya aturan yang mengatur secara teknis bagaimana bentuk pelaksanaan pendidikan profesi, hak dan kewenangan para pihak 
dalam hal ini dokter pendamping dan dokter Internsip secara khusus serta bentuk pemeriksaan dan proses pemberian sanksi terkait kesalahan tersebut. Berdasarkan hasil penelitian dan analisa, penyusunan dapat memberikan beberapa kesimpulan bentuk pertanggungjawaban dokter Internsip terhadap kesalahan dalam pelaksanaan medis, yang bertanggungjawab atas kesalahan pelaksanaan tindakan medis yang dilakukan oleh dokter Internsip ialah dokter Internsip, dokter pendamping dan wahana Internsip atau rumah sakit, kemudian bentuk pertanggung jawabannya tetap mengacu pada bentuk pertanggungjawaban perdata, pidana dan sanksi administratif yang sesuai ditetapkan dalam peraturan menteri kesehatan dan peraturan konsil kedokteran Indonesia tentang dokter internsip.

\section{KESIMPULAN}

Hubungan hukum antara Dokter Program Internsip dengan Pasien dalam ilmu kedokteran umumnya berlangsung sebagai hubungan biomedis aktif-pasif, hubungan aktif-pasif ini dimana dokter yang berperan penting dalam dunia kesehatan dan pasien sebagai peran yang pasif, sehingga dalam hal ini yang akan Bertanggungjawab terhadap pelayanan kesehatan yang diberikan kepada pasien, adalah bentuk Pertanggung Jawaban Perdata, Pertanggung Jawaban Hukum Pidana, Tanggung Jawab Hukum Administrasi dan Pertanggung Jawaban Wahana Internsip dokter dan/atau (dokter peserta Internsip, Dokter Pendamping dan Rumah Sakit).

\section{REFERENSI}

Astuti, E. K. (2003). Hubungan Hukum Antara Dokter Dan Pasien Dalam Upaya Penanganan Medis. Semarang.

Bertens, K. (2011). Etika Bio Medis. Yogyakarta: Atma Jaya.

Erwin G. Kristanto. (2012). Clinical Privilage dan Tanggung Jawab Dokter Internsip di Rumah Sakit. Jurnal Biomedik, 4(3).

Fourianalistyawati, E. (2012). Komunikasi Yang Relevan Dan Efektif Antara Dokter Dan Pasien. Journal Psikogenesis, 1(1), 82-87.

H.S., S. (2013). Hukum Kontrak, Teori dan Teknik Penyusunan Kontrak. Jakarta: Sinar Grafika.

IDAI. (2011). Pedoman Pelayanan Medis (2nd ed.). Jakarta: Badan Penerbit Ikatan Dokter Anak Indonesia.

Indriati, N. Y., Wahyuningsih, K. K., Sanyoto, \& Suyadi. (2018). Perlindungan Dan Pemenuhan Hak Anak (Studi Tentang Orangtua Sebagai Buruh Migran Di Kabupaten Banyumas). Mimbar Hukum - Fakultas Hukum Universitas Gadjah Mada, 29(3), 474-487. https://doi.org/10.22146/jmh.24315

Irfan, M., \& Hidayat, S. (2018). Mediasi Sebagai Pilihan Penyelesaian Sengketa Medik Dalam Hukum Positif Indonesia. Jurnal IUS, 6(3).

Irwansyah. (2020). Penelitian Hukum: Pilihan Metode \& Praktik Penulisan Artikel (A. Yunus, ed.). Yogyakarta: Mirra Buana Media.

Likadja, J. A. C. (2015). Memaknai "Hukum Negara (Law Through State)" dalam Bingkai "Negara 
Hukum (Rechtstaat)." Hasanuddin Law Review, 1(1), 75-86. Retrieved from http://pasca.unhas.ac.id/ojs/index.php/halrev/article/view/41/40

Mubasyiroh, R., Despitasari, M., \& Hendarwan, H. (2018). Peningkatan Pengetahuan Upaya Kesehatan Masyarakat pada Dokter Internsip Berdasarkan Faktor Wahana Puskesmas. Jurnal Kedokteran Dan Kesehatan, 14(1), 26. https://doi.org/10.24853/jkk.14.1.26-38

Muchtar, M. (2016). Etika Profesi dan Hukum Kesehatan. Yogyakarta: PT Pustaka Baru Press.

Nasution, B. J. (2005). Hukum Kesehatan Pertanggungjawaban Dokter. Jakarta: Rineka Cipta.

Peter Mahmud Marzuki. (2014). Penelitian Hukum. Jakarta: Kencana Prenada Media Group.

Sooewono, H. (2007). Batas pertanggung jawaban Hukum Malpraktek Dokter. Surabaya: Srikandi.

Sukohar, A., Sibero, H. T., \& Ratna, M. G. (2015). Penyuluhan Mediasi Sengketa Medik pada Dokter yang akan Diambil Sumpah di Fakultas Kedokteran Unila. JPM Ruwa JUrai, 1(1), 7174.

Sulaiman, S. (2018). Paradigma dalam Penelitian Hukum. Kanun Jurnal Ilmu Hukum, 20(2), 255272. https://doi.org/10.24815/kanun.v20i2.10076

Tutik, T. (2010). Perlindungan Hukum Bagi Pasien. Jakarta: T.Prestasi Pustaka.

Zaeni, A. (2017). Aspek-aspek Hukum Kesehatan Di Indonesia. Depok: Rajawali Pers.

Zubaidi, N., Pratamab, G., \& Al-Fatih, S. (2020). Legal Perspective on Effectiveness of Pre-Work Cards for Indonesian People. Jurnal Bestuur, 8(1). https://doi.org/10.20961/bestuur.42722 